GANDRUNG: Jurnal Pengabdian Kepada Masyarakat

ISSN: 2721-6136 (Online)

\title{
Increase The Immune System With Exercise
}

\author{
Ujang Rohman ${ }^{1}$, Santika Rentika H², Sumardi³, Achmad Nuryadi', Luqmanul Hakim5, Yandika \\ Fefrian $\mathbf{R}^{6}$ \\ 1,2,3,4,5,6Program studi Pendidikan Jasmani, Fakultas Pendidikan Pedagogy dan Psikology \\ Universitas PGRI Adi Buana Surabaya, Jawa Timur Indonesia \\ Email: 1ujang_roh64@unipasby.ac.id, 2santikarain@yahoo.com, 3sumardi.ppi@gmail.com,

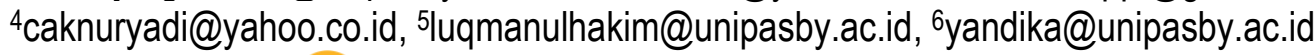

doi https://doi.org/10.36526/gandrung.v2i1.1173

\begin{abstract}
Some of the important factors to monitor during exercise are training load / exercise, recovery, and illness / injury. Training load includes training duration, frequency, and intensity. What is considered during recovery is resting heart rate, fatigue, appetite, and sleep quality. The frequency, type, cause, place / position of the body where the illness / injury occurs, and how long it takes for the illness / injury to occur are important things that should not be overlooked (Malm et al., 2019). By monitoring these things independently at home, it is hoped that sports can take place safely and increase immunity during this corona pandemic. In order to prepare for offline learning, SMPN 1 Perak Jombang needs a lot of references on how to improve the immune system through sports in the pandemic era in order to avoid Covid-19. Starting from knowledge about immunity, increasing immunity by improving nutrition, increasing immunity by exercising and other knowledge that can provide benefits for all.
\end{abstract}

Keyword: Corona Virus, Sports, Immunity

\section{Pendahuluan}

Pada bulan Desember 2019, dunia dikejutkan dengan berita adanya wabah virus corona baru yang diberi nama 2019-novel corona virus (SARS-CoV-2) di kota Wuhan, provinsi Hubei, China. Virus ini juga dikenal dengan nama COVID-19 (Corona Virus Disease 2019) (Dutheil et al., 2020). Dengan adanya pergerakan masyarakat yang masih melakukan perjalanan dan menganggap remeh akan virus ini, maka muncul pandemi virus corona pada tahun 2020. WHO menyatakan terjadi pandemi karena telah menyerang seluruh dunia dan menyebabkan tingginya angka infeksi, morbiditas, dan mortalitas (Chan et al., 2020).

Banyak orang menganggap yang penting olahraga dengan jarak terpisah minimal satu meter dan memakai masker sudah cukup aman. Padahal tidak semua olahraga di luar ruangan itu aman. Jika memang olahraga di luar ruangan aman, mengapa lomba olahraga nasional maupun internasional itu ditunda sampai waktu yang tidak ditentukan? Tak sedikit pula kegiatan olahraga yang dibatalkan dalam skala internasional (Halabachi et al., 2020).

Olahraga sebenarnya memiliki banyak efek positif. Olahraga ini sering disebut aktivitas fisik untuk meningkatkan kesehatan dan kebugaran. Manfaat positif olahraga adalah meningkatkan perkembangan 
GANDRUNG: Jurnal Pengabdian Kepada Masyarakat ISSN: 2721-6136 (Online)

pribadi dan psikososial, tidur lebih nyenyak, bahkan dapat mengurangi ketergantungan terhadap alkohol (Lopez et al., 2016). Beberapa penelitian menyatakan bahwa olahraga dapat mengurangi demensia (pikun). Efek olahraga juga bisa negatif jika dilakukan berlebihan, misalnya kelelahan (burnout), cedera, ataupun luka karena terjatuh atau kurang berhati-hati (Malm et al., 2019).

Olahraga yang dilakukan secara tepat pasti akan membawa dampak positif baik secara fisiologis maupun psikologis. Di masa pandemi ini, haruslah dipilih olahraga yang baik. Jika tidak memilih olahraga yang tepat, bukan tidak mungkin dengan berolahraga malah berisiko terjadi peningkatan penularan COVID-19. Tujuan tinjauan pustaka ini adalah mengetahui olahraga yang aman untuk meningkatkan imunitas tubuh pada masa pandemi COVID-19.

Olahraga di masa corona ini menjadi suatu kebutuhan pokok. Olahraga dapat mengusir kebosanan di rumah, meningkatkan imunitas, mengisi waktu luang, dan meningkatkan energi dalam menjalani rutinitas sehari-hari. Kurangnya aktivitas fisik selama masa pandemi dapat meningkatkan risiko penyakit dan obesitas. Asupan makanan meningkat disertai aktivitas fisik berkurang akan meningkatkan obesitas. Aktivitas fisik yang tepat dapat mengurangi stres dan kecemasan. Kadar endorfin akan meningkat setelah berolahraga (Malt et al., 2019).

Sebenarnya ada penelitian yang mengatakan bahwa olahraga adalah pedang bermata dua. $\mathrm{Di}$ satu sisi menguntungkan, namun di sisi lain dapat membahayakan. Olahraga dikatakan dapat membuat orang awet muda. Namun, tidak jarang kita dengar ada orang yang meninggal di lapangan olahraga karena serangan jantung (Stamakis et al., 2019). Gangguan gastrointestinal bisa juga terjadi jika olahraga berlebihan. Dengan mempertimbangkan berbagai faktor, maka dosis olahraga itu berbeda bagi setiap usia dan kondisi fisik individu (Malm et al., 2019).

Olahraga meningkatkan respon sel dan sistem imun dalam hitungan detik sampai menit setelah mulai berolahraga. Jadi disarankan olahraga secara rutin supaya imunitas terpelihara dengan baik. Olahraga meningkatkan fight or flight stress response, artinya respon tubuh terhadap stress akan lebih baik. Tubuh memiliki kemampuan untuk mengukur dan bereaksi terhadap suatu stres dengan lebih efektif(Zhu, 2020).

Rekomendasi mengenai olahraga pada masa pandemi corona tergantung keadaan kesehatan masing-masing individu. Pada orang yang sehat atau tak memiliki gejala apapun, dianjurkan untuk olahraga di lingkungan pribadi (misalnya di rumah) dengan ventilasi yang bagus dan menggunakan alat pribadi. Untuk penderita infeksi saluran pernapasan atas dengan gejala hanya terbatas di atas leher, maka diperbolehkan olahraga ringan sekitar 10 menit dengan tes jogging dahulu, jika kondisi memburuk, maka segera dihentikan dan tidak boleh olahraga sampai sembuh sempurna. Pasien dengan gejala 
GANDRUNG: Jurnal Pengabdian Kepada Masyarakat ISSN: 2721-6136 (Online)

infeksi saluran pernapasan atas yang disertai keluhan di bawah leher, mengalami sakit otot, demam, dan ada gejala saluran cerna, maupun sesak napas atau gangguan organ lain, maka tidak diperbolehkan sama sekali untuk berolahraga sampai sembuh sempurna. Pada masa pandemi ini, semua orang tidak diperbolehkan melakukan olahraga dengan intensitas tinggi, bahkan harus membatalkan semua olahraga kompetisi (perlombaan). Hal ini dilakukan karena orang yang tidak menunjukkan gejala infeksi corona pun dapat menularkan penyakit pada orang lain (carrier) (Halabchi et al., 2020).

Rekomendasi tersebut di atas memiliki beberapa alasan dan latar belakang. Olahraga dengan tingkat/intensitas sedang dapat meningkatkan imunitas tubuh melawan infeksi pernapasan akibat virus. Melakukan aktivitas fisik (olahraga) intensitas sedang dapat meningkatkan netrofil dan sel natural killer serta konsentrasi iga dalam saliva. Inflamasi (peradangan) akan berkurang dan imunitas (kekebalan) tubuh akan meningkat. Yang perlu diingat adalah olahraga dengan intensitas tinggi dapat menurunkan kekebalan dan risiko infeksi pernapasan makin meningkat (Halabchi et al., 2020).

Rekomendasi lainnya adalah berdasarkan kelompok umur sesuai panduan WHO pada tahun 2017. Semua anak dan remaja mulai umur 6-17 tahun disarankan olahraga 60 menit sehari dengan intensitas sedang. Jika olahraga intensitas tinggi, maka frekuensi dapat diperpendek menjadi 3 kali seminggu. Jenis olahraga ini dapat pula diikuti dengan aktivitas penguatan otot 3 kali seminggu. Berlari dan melompat diperbolehkan untuk meningkatkan densitas tulang. Guna olahraga pada usia ini adalah untuk perkembangan otot, tulang, dan saraf; mempertahankan berat badan yang sehat dan mencapai kesehatan mental yang prima; meningkatkan perkembangan sosial, rasa percaya diri, dan memperbaiki kemampuan belajar (Malm et al., 2019).

\section{Metode}

Strategi yang dilakukan untuk mencapai kondisi yang diharapkan, misalnya: PAR (Participatory Action Research); ABCD (Asset Based Community Development); CBR (Community-Based Research); Service learning; Community development, atau metode pengabdian yang lainnya, pihak yang terlibat dan bentuk keterlibatan (patnership), tempat dan waktu kegiatan (lama proses pendampingan). Metode Pada kegiatan pengabdian masyarakat ini dilakukan dengan menggunakan metode partisipatif, yaitu pendekatan yang berorientasi kepada upaya peningkatan peran serta masyarakat sekolah secara langsung dalam berbagai proses dan pelaksanaan. 1. Khalayak Sasaran Sasaran kegiatan pengabdian ini adalah SMPN 1 Perak Jombang yang berperan sebagai peserta kegiatan workshop. 2. Tahapan Persiapan Tahapan persiapan meliputi survei lokasi, setelah itu berkoordinasi dengan pihak SMPN 1 Perak Jombang untuk melakukan izin terkait pelaksanaan kegiatan workshop yang bertempat di aula 
GANDRUNG: Jurnal Pengabdian Kepada Masyarakat ISSN: 2721-6136 (Online)

SMPN 1 Perak Jombang dan tentunya juga dengan memperhatikan protokol kesehatan dan physical distancing. Selain itu kami melakukan workshop terhadap guru SMPN 1 Perak Jombang terkait pentingnya kegiatan ini di masa pandemi covid 19. Menyediakan sarana prasarana yang mendukung berlangsungnya kegiatan pengabdian ini dan kebutuhan konsumsi. 3. Tahapan Pelaksanaan a. Tahap pelaksanaan dilakukan selama 1 hari, yaitu pada tanggal 18 Januari 2021, pada pukul 09.00-12.00 wib. b. Peserta sosialisasi mengisi absensi dan biodata. c. Peserta mengikuti prosedur protokol kesehatan $d$. Peserta menggunakan tempat yang telah disediakan oleh pelaksana. Tahap Evaluasi Akhir Pada tahap ini dilakukan pembuatan laporan tahap akhir, yang berisi laporan dari hasil kegiatan workshop dan kritik yang berkaitan dengan pelaksanaan program.

\section{Hasil dan Diskusi}

Hasil dan Diskusi Kegiatan workshop peningkatan kebugaran jasmani ini dimulai tanggal 18 Januari 2021, pukul 09.00- 12.00 wib dan berlokasi di Aula SMPN 1 Perak Jombang. Pelaksanaan awal peserta sosialisasi mengisi absen terlebih dahulu, kemudian peserta menggunakan tempat yang telah disediakan oleh pelaksana. Pelaksanaan workshop diberikan oleh tim pelaksana pengabdian masyarakat dengan menggunakan laptop, LCD dan michrophone serta materi yang dibagikan ke peserta. Materi terkait olahraga dapat meningkatkan imun dimasa pandemi yang disampaikan dan direkomendasikan adalah jogging, bersepeda dan senam aerobik dengan memperhatikan protokol kesehatan dan physical distancing. Terlihat antusiasme para peserta yang cukup baik, yaitu dengan munculnya beberapa pertanyaan ketika dalam sesi diskusi. Penyampaian materi workshop adalah olahraga dapat meningkatkan imun dimasa pandemi

Pelaksanaan kegiatan Program Pengabdian kepada Masyarakat oleh Tim Dosen Pendidikan Jasmani Universitas PGRI Adi Buana Surabaya berjalan dengan lancar. Para guru SMPN 1 Perak yang berjumlah 53 orang sangat antusias mengikuti setiap kegiatan yang sudah terjadwal. Kedatangan guru selalu tepat waktu yaitu sepuluh menit sebelum kegiatan dimulai. Saat kegiatan melampaui batas waktu sholat dhuhur maka kami mengadakan jeda untuk Ishoma (Istirahat, Sholat, Makan/Coffee break). Semua konsumsi dan coffee break telah disediakan Tim Panitia Dosen Pendidikan Jasmani Universitas PGRI Adi Buana Surabaya.

Kendala yang dihadapi saat pelaksanaan Program pengabdian kepada Masyarakat oleh Tim Dosen Pendidikan Jamani Universitas PGRI Adi Buana Surabaya adalah kurangnya bandwidth internet karena semua guru dan narasumber memakai jaringan internet sekolah, tapi hal ini tidak menyurutkan minat peserta untuk mengikuti kegiatan dengan baik dan sampai selesai. 
GANDRUNG: Jurnal Pengabdian Kepada Masyarakat ISSN: 2721-6136 (Online)

\section{Kesimpulan}

Dalam rangka persiapan pembelajaran luring, SMPN 1 Perak Jombang memerlukan banyak referensi tentang bagaimana meningkatkan sistem imun melalui olahraga di era pandemi agar terhindar dari covid-19. Dimulai dari pengetahuan tentang imun, maningkatkan imun dengan perbaikan nutrisi, meningkatkan imun dengan berolahraga dan pengetahuan lainnya yang dapat memberikan manfaat untuk semua

\section{Daftar Referensi}

Chan, J.F., Yuan, S., Kok, K., To, K.K., Chu, H., Yang, J., Xing, F., Liu, J., Yip, C.C., Poon, R.W., Tsoi, H., Lo, S.K., Chan, K., Poon, V.K., Chan, W., Ip, J.D., Cai, J., Cheng, V.C., Chen, H., Hui, C.K., Yuen, K.Y. (2020). A familial cluster of pneumonia associated with the 2019 novel coronavirus indicating person-to- person transmission: a study of a family cluster. Lancet, 395, 514e523. https://doi.org/10.1016/S0140-6736(20)30154-9.

Chen. P., Mao, L., Nassis, G.P., Harmer, P., Ainsworth, B.E., Li, F. (2020). Wuhan coronavirus (2019-nCoV): The need to maintain regular physical activity while taking precautions. J Sport Health Sci., 9 (2), pp.103-4.Dutheil, F., Baker, J.S., Navel V. 2020. COVID-19 as a factor influencing air pollution?Environmental Pollution, 263, pp.1-3.

Halabchi, F., Ahmadinejad, Z., Ghaffari, M.S. (2020). COVID-19 Epidemic: Exercise or Not to Exercise; That is the Question! Asian J Sports Med. In Press.doi:10.5812/asjsm.102630.

Lopez, V.F.J., Rodriguez, G.P.L., Garcia, C.E., Perez, S.J.J. (2016). Relationship between sport and physical activity and alcohol consumption among adolescents students in Murcia. Arch. Argent. Pediatr.,114, pp.101-106.

Luan, X., Tian, X., Zhang, H., Huang, R., Li, N., Chen, P., et al. (2019). Exercise as a prescription for patients with various diseases. J Sport Health Sci.,8, pp.422-41.

Malm, C., Jakobsson, J., Isaksson A. (2019). Physical Activity and Sports Real Health Benefits: A Review with Insight into the Public Health of Sweden. Sports, 7(127), pp.1-28.

Wilder-Smith, A., Freedman, D.O. (2020). Isolation, quarantine, social distancing and community containment: pivotal role for old-style public health measures in the novel coronavirus (2019-nCoV) outbreak. J. Trav. Med., 27(2), pp.1-4.

Zhu, W. (2019). If you are physically fit, you will live a longer and healthier life: An interview with Dr. Steven N. Blair. J Sport Health Sci., 8, pp.524-6.

Zhu, W. 2020. Should, and how can, exercise be done during a coronavirus outbreak? An interview with 
GANDRUNG: Jurnal Pengabdian Kepada Masyarakat ISSN: 2721-6136 (Online)

Dr. Jeffrey A. Woods. J Sport Health Sci., 9, pp.105-7. 